\title{
THE BENEFITS OF PROVIDING CONTACT WITH PRACTITIONERS IN ROUND TABLE FORUMS: UNDERGRADUATE STUDENT PERCEPCION OF THE EXPERIENCE
}

\section{Cristina del Campo}

Economics and Business School. Universidad Complutense de Madrid (SPAIN) e-mail: campocc@ccee.ucm.es

\section{Begoña Navallas}

Business School. Universidad Autónoma de Madrid (SPAIN)

e-mail: b.navallas@uam.es

\section{María-del-Mar Camacho-Miñano ${ }^{1}$}

Economics and Business School. Universidad Complutense de Madrid (SPAIN) e-mail:marcamacho@ccee.ucm.es

\begin{abstract}
The aim of this paper is to analyse university students' perceptions about the role of auditors that presented some 'hot topics' as a part of an extra-curricular activity at the university. In particular, we want to test (1) the validity of professional experience stories in order to reduce the negative stereotype on the accounting profession and (2) the factors that affect this perception in undergraduates. This paper evidences, through a survey with 388 students, the validity of professional experience activities in order to encourage undergraduates' employability in auditing and accounting firms from the beginning of their studies.
\end{abstract}

Keywords: Auditing, accounting career, training real business cases, accounting stereotypes, multivariate statistics.

\footnotetext{
${ }^{1}$ Corresponding author. Universidad Complutense de Madrid. Campus of Somosaguas. Building $6^{\text {th }}$ Office 63. Department of Financial Accounting and Economics. 28223 Pozuelo-de-Alarcón. Madrid. Spain. Tel.: 003491 3942585. Fax: 0034913942381.
} 


\section{INTRODUCTION}

Many universities around the world offer extracurricular activities, from sports to training or professional activities. Some of them can be round tables, lectures from business professionals, conferences, or workshops, among others. The aim of many of these activities is to give students the possibility to orientate their future employability and to improve their capacity towards critical thinking. However, these activities are usually not evaluated so it is necessary to assess them somehow. Asking students about their perceptions might be a way to evaluate them.

Consequently, the aim of this paper is to analyse the perceptions of university students about certain 'hot topics' affecting the role of auditors, presenting some accounting and auditing real life cases as a part of an extra-curricular activity and not under the pressure of their grades. Indeed, the auditor's role is a key factor in market confidence and financial stability, founded on the public interest and legitimacy theory on the auditing profession, as the quality of the financial information and relevance and reliance of the corporate figures are mainly based on auditors' reports and opinions. An academic approach to the public interest concept can be close to the legitimacy theory where public interest is defined by the AICPA as 'the collective of well-being of community of people and institution the profession served', and the FASB mission is understood to "serve the investing public" (Baker, 2005). Following Deegan (2002, p.292) 'organizations exist to the extent that the particular society considers that they are legitimated, and if this is the case, the society "confers" upon the organization the "state" of legitimacy".

In this paper, we want to test the perceived utility and difficulty of the content of a round table forum as a measure of the utility of this kind of supplementary activities. We expect that a high perceived utility of the activity will bring students higher motivation on accounting and auditing related subjects and will help them design their professional career. Thus, it will improve their learning process and enhance the interest of the students on the presented topics conveying a more positive image of the auditing profession.

We employed a sample of 388 undergraduate students of Business Administration related degrees from six different colleges and universities in Spain. All of them 
attended one of the two training round tables entitled 'Accounting, regulation and financial crisis: analysing banks' behaviour' and 'Internal control and the prevention of money laundry', organized by the Madrid section of the auditors' association named the 'Instituto de Censores Jurados de Cuentas de España' (Institute of Chartered Accountants in Spain). We decided to use these two hot topics as the role of an auditor is related to strong ethical requirements, and that way students would get a practical approach to real life and hear it first-hand about the world of work, not only with the multidisciplinary approach to the profession but also with its social interest position.

This paper contributes to the literature by bringing new evidence on the relevance of extracurricular activities designed to show professional experiences in order to encourage young undergraduates to study hard, to stimulate their employability and to enhance their critical thinking capacities from the beginning of their university studies. We consider that students are satisfied because they are learning real things while enjoying the experience so it affects positively their readiness to learn as Grandzol and Wynn (2011)'s paper suggests. According to Lizzio, Wilson and Simons (2002) students' perceptions affect their learning process, as the learning process is an interactive system of different variables, including the learning environment and students characteristics (Biggs, 1989), and as students learning evaluations and results are related to their intrinsic motivations (Camacho-Miñano and del Campo, 2014). Additionally, the utility of these activities will help university students bring a more positive perception of the auditing profession, considering it a possible professional career.

The rest of the paper is organized as follows. Next section illustrates the extant literature and then the research questions are presented. Later the study, in particular the context, the sample selection procedure and the methodology used to gather evidence are shown. Finally the empirical results are discussed and the paper concludes highlighting this research main implications and future research. 


\section{EXTRACURRICULAR ACTIVITIES}

One of the main objectives and concerns of colleges and universities is to reach an appropriate employability level. But employability is a complex and vague concept (Andrews \& Higson, 2008), that goes from identifying personal and academic students' skills (Knight \& Yorke, 2004) to other educational outcomes as demographic data affecting graduate employment (Smiths, McKnight \& Naylor, 2000). Indeed, graduate employability is a multifaceted process, and encompasses academic performance, career management skills and labour market awareness (Rothwell \& Arnorld, 2007). In order to achieve their goals, colleges and universities try to define students' curriculum, skills and knowledge, avoiding the possible gap between students profile and the perspective of employers (Andrews \& Higson, 2008). The definition of those skills, required and valued by employers, has been discussed for the last decades to fulfil the expected profile of graduates to meet the needs of the labour market (Elias \& Purcel, 2004).

There are different approaches and learning objectives for business and accounting studies in the literature. Barr and Tagg (1995) defined the instruction paradigm as a traditional learning approach based on the lecture method, which is fundamental in knowledge transfer but it is not enough for skills development. Following the foundation of constructivism, a new approach was developed, placing the student on the centre of the learning process, enhancing his/her active role in constructing his/her own knowledge, far from the lecture based methodology (Agrawal \& Kahn, 2008). Active learning includes different methods, such as class discussions, cases studies or seminar presentations. However, active methodology cannot be used if no motivation is achieved from students. Thus, students who recognize the importance of what they are learning and enjoy the experience will go beyond the minimum requirements, and this will affect their readiness to learn (Grandzol \& Wynn, 2011). Another tool for active learning is extra-curricular activities, usually voluntary, casual, and business-focused but part of the learning environment. Prior research has shown that participation in extra-curricular activities have many benefits for students as they can acquire critical thinking skills (Tieu et al., 2010), social skills (Gellin, 2003) or leadership skills (Rubin, Bommer \& Baldwin, 2002), competences that are highly valued by audit employers. 
Consequently, undergraduate students' learning is a complex process involved through experiences that occur not only inside of the classroom but outside. These latter experiences may play an important role in students' learning environment (Tieu et al., 2010). Lecture approach is extremely important in transferring knowledge, but has to be complemented with other learning activities to both enhance students' analytical and critical thinking skills (Lizzio et al., 2002) and increase their motivation, as previous literature show students' engagement increases with the participation on extra-academic activities such as paid work (Coates, 2015).

Extra-curricular activities are usually voluntary, casual, and business-focused and part of the learning environment, are expected to affect positively students' performance (Kuh et al., 2008) and help to promote students learning and improve the multifaceted nature of student engagement (Krause \&Coates 2008). But oftentimes there is no evaluation of this kind of activities, as university managers are more focused on quantity than in quality (Astin, 1999). As it was already mentioned before, research has shown that participation in extra-curricular activities have many benefits for students: critical thinking skills (Tieu et al., 2009), social skills (Gellin, 2003), leadership skills (Rubin et al., 2002). However, university managers or lecturers have good perceptions of extracurricular activities but they do not take into account students' perceptions that, together with expectations, are key elements in any learning environment (Lizzio et al., 2002; Nijhuis et al., 2005). Additionally, there is not much research about efficacy of teaching resources (in and out of the class) in the field of business (Agnello et al., 2011). Activities like these extra-curricular activities are a good way to improve one of the components of graduate employability, apart from those soft skills and hard skills mentioned, that are work experience and work based learning (Andrews \& Higson, 2008).

\section{RESEARCH QUESTIONS}

In this paper, we study the impact of activities for undergraduates related to auditing profession, through a proxy measured by the utility of an extra-academic activity, a round table of young auditors. We use this proxy because past experiences asking directly about their audit personal perceptions in a round table showed almost $100 \%$ of 
total satisfaction. We assumed that students that are satisfied with this kind of activities change into a positive perception of the accounting profession. Hence our first research question states that:

RQ1: Do students perceive positively real-life focused activities based on professional experiences?

Measuring the positive perception by the proxy of utility, we expect high values of this proxy as a way to validate this extracurricular activity. The positive perception of this activity could be a way to boost students to become professional auditors.

Additionally, gender is of a special interest when studying the auditing and accounting professions. Some authors point out that women have a higher presence in junior positions, but they are underrepresented on firm's board (Dambrin \& Lambert, 2008) and they tend to work in smaller companies (Broadbent \& Kirkham, 2008). These circumstances can be explained as women are subject to a higher pressure than men when facing childcare and mothering, affecting their professional career at a partner level (Windsor \& Auyeung, 2006; Khalifa, 2013). This circumstance has been a question of interest not only for Anglo-Saxon countries (Barker \& Monks, 1998) but also for other European countries like France (Dambrin \& Lambert, 2008), Spain (Carrera, Gutiérrez \& Carmona, 2001) or even Asian countries like Japan (Komori, 2008), showing that cultural factors affect the social women's role, although a glass ceiling remains for all those different contexts (Broadbent \& Kirkham, 2008). This study will try to fill in this gap so the second research question is:

RQ2: Is there any difference when measuring the positive perception with the professional experience stories activity by gender?

Following previous literature, there are significant differences in terms of students' attitude mainly based on experience and gender. We do not know if size or type (private vs. state-owned) of college/university or other factors could condition students' perceptions so our third research question states that:

RQ3: What are the factors affecting students' perception for this activity? 
The answer to this question is important not only for lecturers or college/university staff but mainly for auditing firms because students will become their workers and partners and being well-prepared from the freshman year is an investment on good professionals.

\section{METHOD}

\section{Study sample and context}

The context of this study is a basic approach between a professional association of auditors and undergraduate students in order to achieve two main objectives: on one hand to test the validity of professional experience stories, and on the other hand to study the factors that affect this perception in university students. Two round tables were held to bring young auditors back to several Spanish colleges and universities located in the area of the capital city, Madrid. Spain is an interesting environment for our research topic because audit work is not considered a 'profession' but is merely regarded as an 'occupation' (Carrera \& Carmona, 2013).

The first round table took place during the academic year 2011/12 under the title 'Accounting, Regulation and financial crisis: analysis of bank's behaviour', where three young professionals from some of the most relevant international auditing firms, presented a ten-minute speech supported by a personal slide presentation followed by a debate where students posed them questions. The first one talked about the banking system in Europe, the second one about accounting issues for banking financial statements and the last one about the role of the auditor in this context of the current financial crisis.

A second round table entitled 'Internal control and prevention of money laundering' was held during the academic year 2012/13 also as a voluntary out-of-class activity. The first professional talked about internal controls in firms, its importance and how to develop it. The second one spoke out in defence of ethical behaviours of managers and auditors about money laundering and frauds and the third one made a presentation about the way to prevent and control companies' money laundering with the help of audit firms. 
Both round tables were organized by a well-known and prestigious professional organism of auditors in Spain. They were announced in accounting lectures and also through official communication channels (web pages, internal TV channel, billboards...) in each university. All of the speakers used a non-specific language and many life business examples, very easy to be understood by freshmen and sophomore, the main target of the present study as two thirds of the students' gains in knowledge and cognitive skill development are expected to occur in the first two years of college (Pascarella \& Terenzini, 2005). Additionally, as students make progress through the courses, their learning style preference changes: first years students prefer an assimilation learning style (Baker, Simon \& Bazeli, 1986) defined by abstract conceptualization and reflective observation, and more advanced students prefer a convergence style moving to the active experimentation (Brown \& Burke, 1987).

The sample used in this study comes from six different universities and colleges in Spain, two state-owned and four private ones: 170 students from state universities and 218 from the four private ones. A total number of 388 students were considered, $52 \%$ females, with mean age 20.01 (range: 17-47). Although attendees were studying a variety of degrees (Law, Economics, Business Administration, Finance ...), the majority $(70.23 \%)$ was formed by students of the Business Administration Bachelor degree. Finally $62 \%$ of the sample were freshmen and only $2 \%$ senior.

\section{Instrument}

An 'ad-hoc' pen and paper survey of nine items, additionally to gender, age, year at university, degree and university, was carried out at the end of the round tables in each one of the six previously mentioned universities. Beforehand, the organizer explained the objective of the research and the procedure. All survey answers were anonymous and none of the students in any of the round tables refused to answer the questionnaire. We asked about the satisfaction of the activity content, their initial expectation, two questions about pros and cons of the activity and if they would attend again if another similar round table were organised. In addition, we asked an open question about some other interesting extra academic activities.

We wanted to evaluate the validity of those professional experiences so there were also three Likert-type items on students' perceptions ranging from 1 (the worst) to 10 (the 
best) proposed in order to know the level of personal perception of utility, difficulty and total satisfaction with the round table.

As it has been already mentioned before, it is important to highlight that we decided not to use a direct question related to the auditor's image. According to the authors' previous experience, students' answer to this question has no statistical significance because asking whether this experience had changed his/her image of accountants would give a positive answer in more than $95 \%$ of the cases.

\section{Data analysis}

In the present study there are some missing data due to non-response to some of the questions, fact that might pose a problem because loss of data can lead to loss of statistical power and bias in parameter estimates (Roth, 1994). But because of the survey design, the missing data cannot be estimated. Thus those cases with missing data were not considered in the analysis, although they represent a very small percentage.

There are many approaches available for statistical inference, but as in our case we want to analyse responses to the items with groups being the independent variable both the Mann-Whitney rank (Wilcoxon, 1945) and Kruskal-Wallis tests at 0.05 significancelevel will be used (Cohen, Manion \& Morrison, 2000). Both tests provide the same type of results as an analysis of variance, but based on the ranks and not the means of the responses with the only difference that the first one is for two samples while the last one is for more than two samples.

In addition, trying to find an explanation about the factors that condition students' perception of the round table contents, a logistic regression has been carried out with the responses of the activity attendees.

Finally, in order to study the relation between the categorical variables, Multiple Correspondence Analysis (MCA) was used (Greenacre, 2007). MCA, a method aimed specifically at quantifying categorical data, works in a similar way to principal components analysis, in that the total variance is defined and then it is decomposed optimally along so-called 'principal axes' detecting and representing the underlying structures in the data set. Specifically, MCA assigns numerical scale values to the response of categorical variables, with certain optimal properties, that provide maps of the relationships between them. 


\section{RESULTS AND DISCUSSION}

Descriptive statistics of all categorical variables have been carried out (see table 1). For the contents of the round table, $92.5 \%$ of round table attendees were satisfied with the activity although 3\% did not answer the question. Related to whether the activity met their initial expectations, $76 \%$ of participants agreed but $22 \%$ considered that their initial expectations were not in line with the young auditors' presentations. At this point, perhaps it may be worthwhile for other round tables to know why one student out of four did not find the activity aligned with his/her initial expectations. The students' satisfaction result is in line with Kolb and Kolb (2009) that highlights that experiencing and reflecting activities are better for students' learning process than lecture methods. In addition, if students are satisfied is because they are learning while enjoying the experience so it affects positively their readiness to learn as Grandzol and Wynn (2011)'s paper suggests. We think that non-grading activities as the present one are even more effective for students who are concerned about learning because there is no stress (Robotham and Julian, 2006).

Table 1. Categorical variables descriptives

\begin{tabular}{llcc}
\hline \multicolumn{1}{c}{ Variable } & Categories & Frequencies & $\%$ \\
\hline University & State-1 & 107 & 30.925 \\
& State-2 & 39 & 11.272 \\
& Private-1 & 65 & 18.786 \\
& Private-2 & 41 & 11.850 \\
& Private-3 & 32 & 9.249 \\
& Private-4 & 62 & 17.919 \\
\hline Gender & Male & 163 & 47.110 \\
& Female & 183 & 52.890 \\
\hline Expectations & Yes & 295 & 76.031 \\
& No & 56 & 14.433 \\
& N/A & 37 & 9.536 \\
\hline Satisfied & Yes & 359 & 92.526 \\
& No & 17 & 4.381 \\
& N/A & 12 & 3.093 \\
\hline Sentence & $\mathrm{a}$ & 92 & 26.590 \\
& $\mathrm{~b}$ & 206 & 59.538 \\
& $\mathrm{c}$ & 37 & 10.694 \\
& $\mathrm{~d}$ & 11 & 3.179 \\
\hline Cons & $\mathrm{a}$ & 66 & 17.010
\end{tabular}




\begin{tabular}{llcc} 
& b & 63 & 16.237 \\
& $\mathrm{c}$ & 108 & 27.835 \\
& $\mathrm{~d}$ & 144 & 37.113 \\
& N/A & 7 & 1.804 \\
\hline Repeat & Yes & 325 & 84.416 \\
& No & 32 & 8.312 \\
& N/A & 28 & 7.273 \\
\hline
\end{tabular}

Asking about the sentence that best summarises the activity, 57\% said that 'at the round table, I have learned to know the usefulness of the theoretical contents received in the degree but combined with a dynamic and real approach' (sentence b) while $25 \%$ agreed with the sentence 'the presentation has analysed part of the content of some of the subjects of the degree from a practical approach' (sentence a). With these answers, the round table attendance is a proxy of the interest that students have in real life auditing and accounting profession, because it was a voluntary activity. It is worthwhile highlighting that only $5 \%$ of the attendees choose the worst option 'at the presentation, I have not learned anything interesting' (sentence d). In relation with the disadvantages of the round table, there is not a clear answer. $37 \%$ of the students chose the option 'the contents are very complex' (Cons-a); 28\% the answer 'speakers do not explain concepts well enough' (Cons-b); 16\% 'I do not have enough knowledge to understand the presentation completely' (Cons-c) and the rest 'I have not found problems to be highlighted' (Cons-d). However, more than 8 out of 10 students would repeat the activity if it would to be offered again and only $8 \%$ will not attend again this kind of activity. Furthermore, as students are willing to participate in this kind of activities, universities and companies could organise more real business case activities in order to boost their critical thinking and social skills as in Tieu et al. (2010) and Gellin (2003).

Curiously enough, in relation to the open question, many students asked for more round tables from other subjects (marketing, human resources...), in addition to training and visit to real businesses or official stock markets. This result is in line with other studies about university students' preferences of learning resources related to business (Agnello et al., 2011).

As it was already stated, the data come from two different academic years with two different topics for the round tables, so a homogeneity test on the quantitative variables becomes necessary. Results for the Mann-Whitney test appear on Table 2. Only the 
variable 'Total satisfaction' is significative $(p$-value $<0.05)$ so we reject the hypothesis of both years being homogeneous. But for both utility and difficulty we cannot reject the hypothesis of both years' data being homogeneous ( $\mathrm{p}$-value >0.05). Consequently, we will use the utility variable as a proxy for answering our research questions.

Table 2. Mann-Whitney test (two tailed)

\begin{tabular}{|l|l|r|r|r|}
\hline & $\mathrm{U}$ & Expected value & Variance (U) & p-value \\
\hline Utility & 17096.000 & 18564.000 & 1162321.758 & 0.173 \\
\hline Difficulty & 16903.000 & 18552.500 & 1167212.167 & 0.127 \\
\hline Total satisfaction & 13666.000 & 18462.000 & 1128059.544 & $<0,0001$ \\
\hline
\end{tabular}

The main quantitative variables for this study are presented in Table 3. By gender, on average, females have higher values for both utility and difficulty and they are more consistent (standard deviations are smaller) than males. Furthermore, previous literature says that there are gender differences on the perception of accounting profession, so a Mann-Whitney test was run in order to test if those differences were statistically significant. There are only statistically significant differences by gender on utility level (Mann-Whitney test $\mathrm{p}$-value $=0.005)$, but not on difficulty (Mann-Whitney test $\mathrm{p}$-value $=0.595)$ meaning that, in the round table, females perceived more utility than males. This female's perception could be related to the different notions of professionalism by gender (Khalifa, 2013). In addition, the new role of females in society is quickly changing because fewer women are willing to face childcare and mothering. Hence, this perception could change the women's role on accounting and auditing firms in the future whether more females are 'attracted' by this profession.

Table 3. Quantitative variables descriptives

\begin{tabular}{c|ccc|ccc|}
\hline & \multicolumn{3}{|c|}{ Utility } & \multicolumn{3}{c|}{ Total Satisfaction } \\
\cline { 2 - 7 } & Mean & St.Dev. & Median & Mean & St.Dev. & Median \\
\hline Private-1 & 6.682 & 1.852 & 7.000 & 7,385 & 2,583 & 7,000 \\
Private-2 & 6.605 & 1.417 & 7.000 & 6,761 & 1,562 & 7,000 \\
Private-3 & 6.232 & 1.970 & 6.000 & 6,900 & 2,790 & 7,000 \\
Private-4 & 7.455 & 1.834 & 8.000 & 7,664 & 2,592 & 8,000 \\
State-1 & 7.339 & 1.552 & 7.000 & 7,564 & 0,941 & 8,000 \\
State-2 & 6.350 & 2.159 & 7.000 & 6,317 & 2,677 & 6,000 \\
\hline Female & 7.170 & 2.771 & 7.000 & 7,276 & 1,698 & 7.000 \\
Male & 6.603 & 3.965 & 7.000 & 7,111 & 2,901 & 7.000 \\
\hline Total & 6.894 & 1.852 & 7.000 & 7.196 & 2.273 & 7.000 \\
\hline
\end{tabular}


Studying the differences by college/university, on average, Private-4 and State-1 students perceived the activity better than others and there are differences statistically significant for utility (Kruskal-Wallis test p-value $=0.000$ ) but not for difficulty (Kruskal-Wallis test $\mathrm{p}$-value $=0.463$ ). It means that this extra-curricular activity is better perceived by students from the largest college/university (State-1) and the smallest one in terms of number of students (Private-4). Colleges and universities use these activities with different frequency and in different contexts, and this variety may explain the differences among them: these non-graded activities are novel and this could affect students' perceptions at the beginning, similar to what happened with multimedia resources (Walker, Cotner, \& Beermann, 2011). Talking to lecturers of all six colleges and universities, they said that the marketing of extracurricular activities strongly condition results. So students from colleges/universities that offer these activities through Twitter, email or Facebook (students' more used communication channels nowadays) might have better perceptions than the other ones.

The correlation between the two quantitative homogenous variables (utility and difficulty) is 0.083 . So there is almost no relation between the two variables, hence we can consider them independent.

In order to explain students' satisfaction of the proposed extra-curricular activity, the utility variable was split in three parts: high (equal or higher than 8 out of 10), medium (between 5 and 7) and low (less or equal than 4). Only $9 \%$ of the total sample presents low values meaning that, in general, this activity was very well perceived by students.

Trying to find an explanation about the factors that condition the perceptions of students for the extra academic activity as a measure of the incentives to the auditing and accounting profession, a multinomial logistic regression was run to identify the factors that influence the utility of the professional stories activity. All goodness-of-fit statistics give quite bad results $\left(-2 \log (\right.$ Likelihood $)=611.588$, Nagelkerke pseudo $\mathrm{R}^{2}=0.249$, Correct Prediction $=57.10 \%$ ), but the Wald statistic allows us to identify that the factors that have more influence are the variables 'university', 'gender' and 'sentence' (see Table 4). So MCA was used to identify the relationships between the various possible categorical values of 'university', 'gender', 'sentence' and the discretization of the variable 'Utility' (D_utility). 
Table 4. Logistic regression for D_utility

\begin{tabular}{|c|c|c|c|c|c|}
\hline Category & Source & Value & $\begin{array}{c}\text { Standard } \\
\text { error }\end{array}$ & $\begin{array}{c}\text { Wald } \\
\text { Chi-Square }\end{array}$ & $\mathrm{Pr}>\mathrm{Chi}^{2}$ \\
\hline \multirow[t]{18}{*}{ High } & Intercept & 2.336 & 0.498 & 21.990 & $<0.0001$ \\
\hline & DIFICULTY & 0.000 & 0.000 & & \\
\hline & UNIVERSITY-Private-1 & 0.000 & 0.000 & & \\
\hline & UNIVERSITY-Private-2 & 0.000 & 0.000 & & \\
\hline & UNIVERSITY-Private-3 & 0.000 & 0.000 & & \\
\hline & UNIVERSITY-Private-4 & 1.296 & 0.656 & 3.896 & 0.048 \\
\hline & UNIVERSITY-State-1 & 1.603 & 0.691 & 5.380 & 0.020 \\
\hline & UNIVERSITY-State-2 & -0.355 & 0.532 & 0.445 & 0.505 \\
\hline & GENDER-Female & 0.000 & 0.000 & & \\
\hline & GENDER-Male & -1.015 & 0.444 & 5.224 & 0.022 \\
\hline & Sentence-a & -0.518 & 0.588 & 0.775 & 0.379 \\
\hline & Sentence-b & 0.000 & 0.000 & & \\
\hline & Sentence-c & -2.963 & 0.648 & 20.925 & $<0.0001$ \\
\hline & Sentence-d & -3.468 & 0.868 & 15.949 & $<0.0001$ \\
\hline & Cons-a & 0.000 & 0.000 & & \\
\hline & Cons-b & 0.000 & 0.000 & & \\
\hline & Cons-c & 0.000 & 0.000 & & \\
\hline & Cons-d & 0.000 & 0.000 & & \\
\hline \multirow[t]{18}{*}{ Medium } & Intercept & 2.308 & 0.479 & 23.240 & $<0.0001$ \\
\hline & DIFICULTY & 0.000 & 0.000 & & \\
\hline & UNIVERSITY-Private-1 & 0.000 & 0.000 & & \\
\hline & UNIVERSITY-Private-2 & 0.000 & 0.000 & & \\
\hline & UNIVERSITY-Private-3 & 0.000 & 0.000 & & \\
\hline & UNIVERSITY-Private-4 & 0.393 & 0.635 & 0.382 & 0.536 \\
\hline & UNIVERSITY-State-1 & 1.196 & 0.670 & 3.189 & 0.074 \\
\hline & UNIVERSITY-State-2 & -0.681 & 0.489 & 1.943 & 0.163 \\
\hline & GENDER-Female & 0.000 & 0.000 & & \\
\hline & GENDER-Male & -0.582 & 0.422 & 1.902 & 0.168 \\
\hline & Sentence-a & 0.307 & 0.571 & 0.288 & 0.592 \\
\hline & Sentence-b & 0.000 & 0.000 & & \\
\hline & Sentence-c & -1.144 & 0.497 & 5.307 & 0.021 \\
\hline & Sentence-d & -2.260 & 0.635 & 12.658 & 0.000 \\
\hline & Cons-a & 0.000 & 0.000 & & \\
\hline & Cons-c & 0.000 & 0.000 & & \\
\hline & Cons-d & 0.000 & 0.000 & & \\
\hline & Cons-b & 0.000 & 0.000 & & \\
\hline AIC: 308.031 & $\mathrm{R}^{2}$ (McFadden): 0.334 & $\mathrm{R}^{2}(\operatorname{Cox}$ & $\begin{array}{l}\text { and Snell): } \\
.315\end{array}$ & $\mathrm{R}^{2}$ (Nagelker & e): 0.465 \\
\hline \multicolumn{6}{|c|}{ Test of the null hypothesis $\mathrm{H} 0: \mathrm{Y}=0.402$ (Variable D_utility) } \\
\hline Statistic & DF & \multicolumn{2}{|c|}{ Chi-square } & \multicolumn{2}{|c|}{$\operatorname{Pr}>\mathrm{Chi}^{2}$} \\
\hline$-2 \log ($ Likelihood $)$ & 14 & \multicolumn{2}{|c|}{88,271} & \multicolumn{2}{|c|}{$<0.0001$} \\
\hline Score & 14 & \multicolumn{2}{|c|}{97,013} & \multicolumn{2}{|c|}{$<0.0001$} \\
\hline Wald & 14 & \multicolumn{2}{|c|}{68,772} & \multicolumn{2}{|c|}{$<0.0001$} \\
\hline
\end{tabular}


MCA locates all the categories in a Euclidean space. The first two dimensions of this space (see figure 1), explaining $70.43 \%$ of the original adjusted inertia, are plotted to examine the associations among the categories. The interpretation is based on points found in approximately the same direction from the origin and in approximately the same region of the space, although in this case the first axe explains already $55.79 \%$ so this is the more explicative dimension. The top-right quadrant of the plot shows that the categories State-2 and Private-3 colleges/universities have similar results, and that low values of utility and Sentence-d are associated. Proceeding clockwise, the categories Private-1, Private-2, Male, Medium values for utility and Sentence-c are associated. State-1 is associated with Sentence-a. Finally there seems to be a link between Sentence-b, Females, and High values for utility, and those are the responses for students in Private-4.

Figure1

\section{Symmetric variable plot (axes F1 and F2: $70.43 \%$ )}

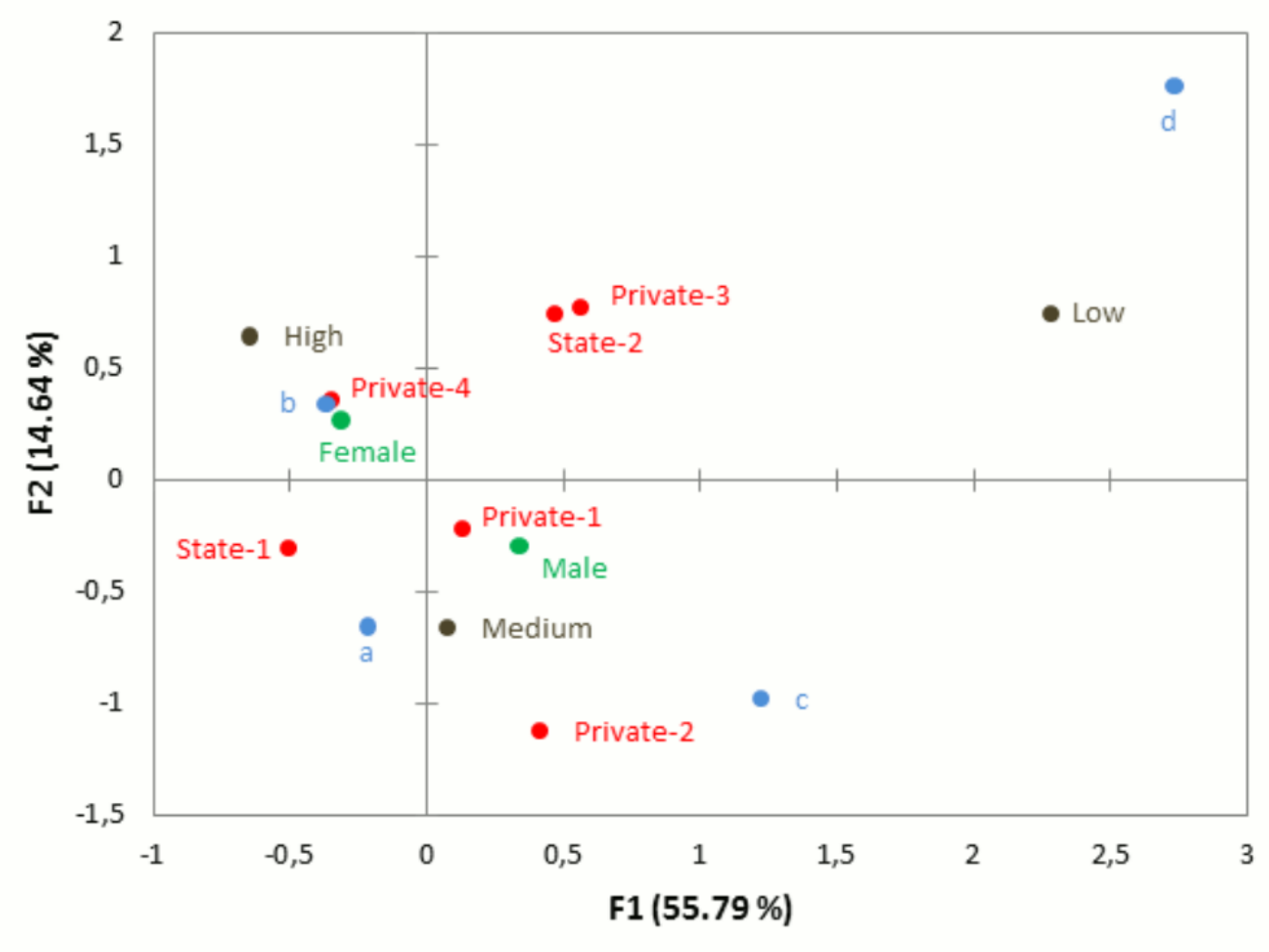


Consequently, the factors that are associated with the better perceptions of the round tables are to be female and to think that 'at the round table, I have learned to know the usefulness of the theoretical contents received in the degree but combined with a dynamic and real approach' (sentence b). The medium perceptions of the round tables are linked to male, private universities and to think that 'the presentation has analysed part of the content of some of the subjects of the degree from a practical approach (sentence a). Logically, students that think that 'at the presentation, I have not learned anything interesting' (sentence d) have the worst perceptions of the round tables.

\section{CONCLUSIONS, LIMITATIONS AND FUTURE RESEARCH}

The aim of this study was to analyse the validity of an extra academic activity and the motivation of students to a concrete subject such as accounting and auditing. This study was carried out through a very specific round table about the role of auditing related to internal control of business and prevention of money laundering.

As it has been already mentioned, the auditing and accounting profession role is extremely important for stakeholders and market stability, as global investors are concerned about the integrity of financial statements (Lobo \& Zhou, 2010). And this circumstance explains the legitimacy of the profession of public interest from a broader social context. Thus, in accordance with the legitimacy theory and the social contract theory, we consider necessary to change the future professionals' perceptions. The main conclusion is that this kind of activity is perceived by students as useful but difficult, although $92.5 \%$ of round table attendees were satisfied with the activity. It means that these professional activities have a positive impact on students as they considered them interesting and useful even though they had some difficulties to fully understand the explanations. Lecturers and organizers of this kind of extracurricular activity may be pleased with the work but more theoretical explanations previously to round tables may increase the satisfaction level of attendees. Moreover, there are only statistically significant differences across gender and across university related to utility. This finding justify different ways of motivation to the career depending on gender, perhaps due to cultural and social conditionings. 
The results of this paper have interesting implications for all the stakeholders involved in activities out of class. For professionals it is important to know that students are, in average, satisfied with this kind of proposals. After several worldwide financial scandals like the collapse of Enron and WorldCom in the USA or Parmalat or Gowex in Europe, the accounting and auditing profession has shown its concern for the gap between the professional career offered and a negative perception. Activities like the held round table will bring a better image of auditors, as professionals with strong ethical requirements, able to deal with different industries and work in teams. They are labour models for them and they may increase their motivation for their professional roles. Accounting and auditing firms have been increasing their presence in different media and investing to attract talent from university. But we consider that it might be more effective to bring them to college to show students their daily work. Additionally gender-focused ad campaigns should be carried out because males and females have different perception about professional careers. Furthermore, this kind of activity could fill in the gap between the theoretical and practical contents, one of the most common complaints from recent graduates. Future professionals that may not become auditors they will bring with them a positive image of the role of the auditor and its social relevance, affecting their future performance and the way they will relate with these professionals along their careers.

Also, lecturers should adjust their curricular contents to professional activities in order to avoid a long distance between university studies and profession, boosting to accounting and auditing career. For example, there are no curricular contents about prevention of money laundering in any undergraduate degree of the universities participating in our study.

Finally, this paper is not out of limitations although it provides an opportunity for future research, which could examine the generality of the results through a bigger sample or even between real professional and students in order to find the more interesting way to offer knowledge. A longitudinal study could also provide evidence on the changing patterns over time. 


\section{References}

Agnello, V., Pikas, B., Agnello, A.J. \& Pikas, A. (2011). Today's learner, preferences in teaching techniques. American Journal of Business Education, 4(2), 1-9.

Agrawal, D. K. \& Kahn, Q.M. (2008). A quantitative assessment of classroom teaching and learning in engineering education. European Journal of Engineering Education, 3, 85-103.

Andrews, J \& Higson, H (2008). Graduate employability, "Soft Skills versus Hard Business Knowledge: A European Study”. Higher Education in Europe, 33, 410422.

Astin, A.W. (1999). Student involvement: A developmental theory for higher education. Journal of College Student Development, 40, 518-529.

Baker, C.R. (2005). What is the meaning of the public interest?. Accounting, Auditing and Accountability Journal, 18(5), 690-703.

Baker, R.E., Simon, J.R. \& Bazeli, F.P. (1986). An assessment of the learning style preferences of accounting majors. Issues in Accounting Education, I(1), 1-12.

Barker, P.C. \& Monks, K. (1998). Irish women accountants a career progression: a research note. Accounting, Organization and Society, 23(8), 813-23.

Barr, R.B. \& Tagg, J. (1995). From teaching to learning - A new paradigm for undergraduate education. Change, nov/dic, 13-25.

Biggs, J.B. (1989). Approaches to the enhancement of tertiary teaching. Higher Education Research and Development, 8, 7-25.

Broadbent, J. \& Kirkham, L. (2008). Glass ceilings, glass cliffs or new worlds?. Revisiting gender and accounting. Accounting, Auditing and Accountability Journal, 21(4), 465-473.

Brown, H.D. \& Burke, R.C. (1987). Accounting education: a learning-styles study of professional-technical and future adaptation issues. Journal of Accounting Education, 5, 187-206. 
Camacho-Miñano, M.M. \& del Campo, C. (2014). Useful interactive teaching tool for learning: clickers in higher education. Interactive Learning Environments, (aheadof-print), 1-18.

Carrera, N., Gutiérrez, I. \& Carmona, S. (2001). Gender, the state and the audit profession: evidence from Spain (1942-88). The European Accounting Review, 10(4), 803-8015.

Carrera, N., \& Carmona, S. (2013). Educational reforms set professional boundaries: the Spanish audit function, 1850-1988. Abacus, 49(1), 99-137.

Coates, H. (2015). Working on a dream: educational returns from off-campus paid work. Journal of Education and Work, 28(1), 66-82.

Cohen, L., Manion, L. \& Morrison K. (2000), Research methods in education. London, England: Routledge Falmer.

Dambrin, C. \& Lambert, C. (2008). Mothering or auditing? The case of Big Four in France. Accounting, Auditing and Accountability Journal, 2(4), 474-506.

Deegan, C. (2002). The legitimizing effect of social and environmental disclosure -a theoretical foundation. Accounting, Auditing and Accountability Journal, 15(3), 282-311.

Elias P. \& Purcell, K. (2004), Is Mass Higher Education Working? Evidence from the Labour Market Experiences of Recent Graduates. National Institute Economic Review, 190, 60-74.

Gellin, A. (2003). The effect of undergraduate student involvement on critical thinking: a meta-analysis of the literature 1991-2000. Journal of College Student Development, 44, 746-762.

Grandzol, C. \& Wynn, P. (2011). Retention, motivation and enjoyment: an exploratory evaluation of the effectiveness of Hands-on Learning. Journal of the Academy of Business Education, Fall, 137-155.

Greenacre, M. (2007). Correspondence Analysis in Practice. Second Edition. Boca Raton, USA: Chapman and Hall. 
Jackson, D (2013). Student Perceptions of the importance of Employability Skill Provision in Business Undergraduate Programs. Journal of Education for Business, 88, 271-279.

Khalifa, R. (2013). Intra-professional hierarchies: the gendering of accounting specialisms in UK accountancy. Accounting, Auditing and Accountability Journal, 26(8), 1212-1245.

Knight, P.T. \& Yorke, M. (2004). Employability. Judging \& Communicating Achievements. York, England: Learning and Teaching Support Network.

Kolb, A.Y. \& Kolb, D.A. (2009). The learning way: meta-cognitive aspects of experiential learning. Simulation and Gambling, 40, 297-327.

Komori, N. (2008). Towards the feminization of accounting practice: lessons from the experiences of Japanese women in the accounting profession. Accounting, Auditing and Accountability Journal, 21(4), 507-38.

Krause, K.-L. \& Coates, H (2008). Students' engagement in first-year University. Assessment \& Evaluation in Higher Education, 33(5), 493-505.

Kuh, G.D., Cruce, T.M., Shoup, R., Kinzie, J. \& Gonyea, R.M. (2008). Unmasking the effects of student engagement on first-year college grades and persistence. The Journal of Higher Education, 79(5), 540-563.

Lizzio, A., Wilson, K., \& Simons, R. (2002). University students' perceptions of the learning environmental and academic outcomes: implications for theory and practice. Studies in Higher Education, 27(1), 27-52.

Lobo, G.J. \& Zhou, J. (2010). Changes in discretionary financial reporting behavior following the Sarbanes-Oxley Act. Journal of Accounting, Auditing and Finance, 25(1), 1-26.

Nijhuis, J. F., Segers, M. S., \& Gijselaers, W. H. (2005). Influence of redesigning a learning environment on student perceptions and learning strategies. Learning Environments Research, 8(1), 67-93.

Pascarella, E.T., \& Terenzini, P.T. (2005). How College Affects Students: A Third Decade of Research. San Francisco, USA: Jossey Bass. 
Rees, G. Godard, S, Fevre, R. \& Furlong, J. (1997). History, Place and the Learning Society: towards a sociology of lifetime learning. Journal of Education Policy, 12(6), 485-497.

Robotham, D., \& Julian, C. (2006). Stress and the higher education student: a critical review of the literature. Journal of Further and Higher Education, 30(2), 107117.

Roth, P.L. (1994). Missing data: A conceptual review for applied psychologists. Personnel Psychology, 47, 537-560.

Rothwell, A., \& Arnold, J. (2007). Self-perceived employability: Development and validation of a scale. Personnel Review, 36, 23-41.

Rubin, R.S., Bommer, W.H. \& Baldwin, T.T. (2002). Using extracurricular activity as an indicator of interpersonal skill: prudent evaluation or recruiting malpractice?. Human Resources Management, 41, 441-454.

Smiths, J., McKnight, A \& Naylor, R. (2000). Graduate Employability: Policy and Performance in Higher Education in the UK. The Economic Journal, 110, 382411.

Tieu, T.T., Pancer, S.M., Pratt, M.W., Gallander Wintre, M., Birnie-Lefcovitch, S., Polivy, J. \& Adams, G. (2010). Helping out or hanging out: the features of involvement and how it relates to university adjustment. Higher Education, 60, 343-355.

Tomlison, M. (2007). Graduate Employability and Student Attitudes and Orientations to the Labour Market. Journal of Education and Work, 20(84), 285-304

Walker, J.D., Cotner, S. \& Beermann, N. (2011). Podcasts and Captures: Using Multimedia to Improve Student Learning in Introductory Biology. Journal of Educational Multimedia and Hypermedia, 20(1), 97-111.

Windsor, C. \& Auyeung, P. (2006). The effect of gender and dependent children on professional accountants' career progression. Critical Perspectives on Accounting, 17(6), 828-44. 
Wilcoxon, F. (1945). Individual comparisons by ranking methods. Biometrics Bulletin, $1,80-83$. 